\title{
AKULTURASI PANCA INDRA METODE YADAIN LI TAHFIZIL QUR'AN
}

\author{
Mochammad Ashabul Yamin \\ Universitas Muhammadiyah Sidoarjo \\ Email: Mochammadashabul417@gmail.com
}

\author{
Anita Puji Astutik \\ Universitas Muhammadiyah Sidoarjo \\ Email: anitapujiastutik@umsida.ac.id
}

\begin{abstract}
The law of maintaining the purity of the Qur'an for all Muslims is fardhu 'ain (mandatory) for Muslims to maintain the authenticity of the contents and lafal of the Qur'an, either by studying, memorizing, thinking and studying the interpretation of the Qur'an. However, many people are afraid of memorizing the Qur'an because the language of the Qur'an is a foreign language and there are many and many verses in common, and what is no less important is the method of memorizing the Qur'an. They don't know yet, how to memorize the Qur'an easily, happily while still paying attention to the reading in accordance with the rules of ulumut tajwid while still paying attention to the tadabur side of the Qur'an when interacting with the Qur'an, either by memorizing or memorizing. Slowly, as time progressed, the methods of memorizing the Qur'an were perfected so that the Tahfiz, al-Qur'an Quarantine Foundation formulated a sophisticated acceleration method that was given to Muslims who were able to answer the needs of the community if they wanted to memorize the Qur'an, namely memorizing the Qur'an using the Yadain Method by using the potential that exists within the five senses, which if in the process of memorizing it is done well with 'ulum al-tajwid, it will make the process of memorizing the Qur'an easy. In this study, the author uses a qualitative approach which the author is directly involved in the field has applied the yadain method. The benefit in the application of this yadain method is to print a memorizer of the Qur'an by knowing the location of the verse and the number of the verse or what can be called (visualization of the Qur'an), then having the ability to memorize what is in the contents of the verses of the Qur'an. So that the messages contained in the Qur'an can reach him through contemplation of the
\end{abstract}


verses of the Qur'an with the assistance of the translation of the Ministry of Religion of the Republic of Indonesia.

Keywords: acculturation; five senses; yadain li tahfizil qur'an

\section{Abstrak}

Hukum menjaga kemurnian al-Qur'an bagi semua muslim ialah fardhu 'ain (wajib) bagi para pemeluk Islam untuk menjaga keotentikan isi dan lafal al-Qur'an, baik dengan mempelajari, menghafal, mentadaburi dan mempelajari tafsir al-Qur'an. Akan tetapi banyak di antara masyarakat yang takut menghafal al-Qur'an dikarenakan bahasa al-Qur'an merupakan bahasa asing dan jumlahnya yang banyak serta mempunyai banyak kesamaan ayat, dan juga yang tidak kalah penting ialah metode dalam menghafal al-Qur'an pun mereka belum ketahui, bagaimana cara menghafal al-Qur'an dengan mudah, dengan bahagia yang tetap mengindahkan bacaan sesuai dengan kaidah 'ulum al-tajwid beserta tetap memperhatikan sisi tadabbur al-Qur'an sewaktu berinteraksi dengan AlQur'an, baik dengan menghafal ataupun memuraja'ah. Perlahan waktu yang terus berjalan mengalami penyempurnaan metode-metode dalam menghafal al-Qur'an sehingga menjadikan Yayasan Karantina Tahfiz alQur'an merumuskan sebuah metode akselerasi yang mutakhir yang diberikan kepada umat Islam yang mampu menjawab kebutuhan masyarakat apabila hendak menghafal al-Qur'an, yaitu menghafal alQur'an Metode Yadain dengan menggunakan potensi yang ada dalam diri berupa panca indera, yang apabila dalam proses menghafalnya dilakukan dengan baik dengan dibekali 'ulum al-tajwid maka akan menjadi mudah proses menghafal al-Qur'an tersebut. Dalam penelitian ini penulis menggunakan pendekatan kualitatif yang penulis secara langsung terlibat di lapangan telah menerapkan metode yadain. Manfaat dalam penerapan metode yadain ini ialah mencetak seorang penghafal al-Qur'an dengan mengetahui letak ayat dan nomor ayat atau yang bisa disebut (visualisasi al-Qur'an), kemudian mempunyai kemampuan mentadaburi apa yang berada dalam isi kandungan ayat al-Qur'an sehingga pesan-pesan yang berada dalam al-Qur'an tersebut dapat tersampai padanya melalui perenungan ayat al-Qur'an dengan dibantu terjemahan Kementerian Agama Republik Indonesia.

Kata Kunci : akulturasi, panca indra, yadain li tahfizil qur'an

\section{Pendahuluan}


Hukum menjaga kemurnian al-Qur'an bagi semua muslim ialah fardhu 'ain (wajib) bagi para pemeluk Islam untuk menjaga keotentikan isi dan lafal al-Qur'an. al-Qur'an merupakan Kalam Ilahi yang Allah Swt. wahyukan melalui perantara malaikat Jibril kepada Nabi Muahmmad saw. untuk disampaikan kepada umat manusia, kabar gembira bagi orang yang mau mengikutinya dan peringatan bagi orang yang dia berpaling pada al-Qur'an yang kemudian disusul ajakan-ajakan pada kebaikan yaitu din al-Islam. Melihat betapa sucinya dan agungnya kalam Allah Swt. yang diturunkan dari laub al-mahfush maka menjadi wajib bagi kita umat Islam untuk senantiasa menjaga, memuliakan, mempelajari dan juga mengamalkan seluruh ajarannya serta mendakwahkannya kepada seluruh umat manusia.

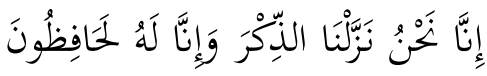

"Sesungguhnya Kamilah Allah Swt. yang menurunkan alZikr (al-Qur'an), dan sesungguhnya Kamilah yang menjaganya." (QS. Al-Hijr: 9) ${ }^{1}$

Bentuk penjagaan Allah Swt. kepada kalamNya yaitu dengan banyaknya umat Islam yang mereka berusaha ingin menghafalnya, senantiasa mengulang bacaan dan juga mempelajarinya sampai hafalan tersebut membekas kuat dalam ingatanya dalam kehidupanya agar senantiasa terjaga dan tidak sampai lupa yang dalam hal ini jumbur ulama menyebutkan bahwa hukum membaca al-Qur'an atau menghafal dan juga mempelajarinya merupakan salah satu bentuk yang dihitung sebagai ibadah dalam rangka mendekatkan diri kepada Allah Swt. ${ }^{2}$

1 Akhmad Syahid, 'Tren Program Tahfidz Al-Qur'an Sebagai Metode Pendidikan Anak', Elementary: Jurnal Ilmiah Pendidikan Dasar, 5.1 (2019), 87 <https://doi.org/10.32332/elementary.v5i1.1389>.

2 Yudhi Fachrudin, 'Pembinaan Tahfizh Al-Quran Di Pesantren Tahfizh Daarul Qur'an Tangerang', Kordinat: Jurnal Komunikasi Antar Perguruan Tinggi $\begin{array}{llll}\text { Agama Islam, } & 16.2 & \text { 325-48 }\end{array}$ <https://doi.org/10.15408/kordinat.v16i2.6445>. 
Tahfiz al-Qur'an adalah bentuk usaha kaum muslimin dalam menjaga keotentikan al-Qur'an baik secara lafal maupun secara penulisan dan juga arti yang dalam hal ini agar orang yang di luar Islam atau yang memusuhi Islam mereka tidak dapat merubah isi kandungan al-Qur'an. ${ }^{3}$ Para penghafal al-Qur'an mempunyai banyak fadbilab ataupun keutamaan-keutamaan tersendiri yang Allah Swt. jamin dan berikan kepada hambaNya yang mau menjaga al-Qur'an yang dengan berbagai keutamaan inilah umat muslim saat ini berlomba dalam menghafal al-Qur'an. Selain itu, para penghafal al-Qur'an mereka adalah salah satu keluarga Allah Swt. di bumi, dijelaskan dalam hadis yang menunjukkan betapa mulianya penghafal al-Qur'an. Adapun hukum tahfiz al-Qur'an sendiri hukumnya fardhu kifayah. Sebagaiamana pendapat Imam Abdul 'Abbas dalam kitabnya al-Syafi'i dalam penjelasan tafsir kalam Allah Swt. QS. Al-Qomar [54]: 17.

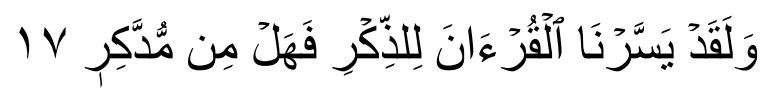

"Dan sesungguhnya telah Kami mudahkan Al-Qur'an untuk pelajaran, maka adakah orang yang mengambil pelajaran." (QS. Al-Qomar [54]: 17)

Menghafal al-Qur'an merupakan bentuk pendidikan yang mampu memberikan jaminan generasi yang baik di masa yang akan datang, output dari pendidikan al-Qur'an dalam hal ini ialah mempunyai karakter atau akhlak yang baik dan membawa masyarakat yang berkemajuan yang beradab, tentunya berlandaskan dengan pedoman umat Islam yaitu al-Qur'an dan sunah yang menjadi akhlak dalam menjalani kehidupan dan bermasyarakat. Hal ini selaras dengan tujuan pendidikan Indonesia yang terkandung di dalam Undang-Undang No. 20 Tahun 2003 Bab 1 Pasal 1 Ayat 1 dalam sistem pendidikan di Indonesia bahwasanya pendidikan adalah usaha sadar dan terencana untuk

3 Fakultas Tarbiyah and others, 'Pengelolaan Program Tahfidz Dalam Pembentukan', 2018, 32-44. 
mewujudkan suasana belajar dan proses pembelajaran agar siswa secara aktif mengembangkan potensi dirinya untuk memiliki kekuatan spiritual keagamaan, pengendalian diri, kepribadian, kecerdasan, akhlak mulia, serta keterampilan yang diperlukan dirinya, masyarakat, bangsa dan negara. ${ }^{4}$ Tercatat dalam sebuah media bahwasanya pendidikan yang berfokuskan pada al-Qur'an pada saat ini di Indonesia ialah yang telah melabelkan diri berasaskan pada al-Qur'an dan sunah ialah Universitas Ilmu alQur'an, Wonosobo, dan juga Institut Ilmu al-Qur'an, Jakarta, dan Sekolah Tinggi Ilmu al-Qur'an, Bantul Yogyakarta, dan masih banyak lain yang saat ini mulai berkembang dan menisbatkan menjadi perguruan tinggi atau sekolah tinggi islam di Indonesia dengan berbagai model modernisasi pendidikan formal dan agama. $^{5}$

Tercatat jumlah penghafal al-Qur'an di Indonesia baik dari kalangan kaum muslimin maupun muslimat. Disebutkan di salah satu majalah harian yaitu majalah Republika ${ }^{6}$ para penghafal alQur'an mencapai angka tujuh juta dari sekian penduduk yang berjumlah 134 juta penduduk, kemudian penduduk Gaza yang menjadi buffazh al-Qur'an yaitu berjumlah 60 ribu orang, sedangkan di negara Libya terdapat satu juta huffaz̧ al-Qur'an dari penduduk yang berjumlah tujuh juta bangsa Arab, sedangkan negara Arab sendiri terdapat enam ribu penghafal al-Qur'an. Sedangkan negara Indonesia sendiri penghafal al-Qur'an terdiri dari 30 ribu di antara penduduknya yang mencapai 250 juta orang. Walaupun jumlah penghafal al-Qur'an sendiri di Indonesia tercatat 30 ribu penduduk yang apabila dipresentasikan tidak kurang dari 0,01\% dari jumlah

4 Asmaul Husna, Evektivitas Progam Tahfidz Al-Qur'an dalam Membentuk Karakter Siswa, Jurnal Islamic and Education Manajemen, 'P-ISSN: 2541-383X e-ISSN: 2541-7088', 3.2 (2018), 220-30.

5 Suci Eryzka Marza, 'Regulasi Diri Remaja Penghafal Al-Qur'an Di Pondok Pesantren Al-Qur'an Jami'atul Qurro' Sumatera Selatan', Intelektualita, 6.1 (2017), 145 <https://doi.org/10.19109/intelektualita.v6i1.1306>.

${ }^{6}$ https://www.republika.co.id/berita/dunia-islam/islamnusantara/10/09/24/136336-jumlah-penghafal-alquran-indonesia-terbanyak-didunia 
penduduk yang berjumlah 250 juta jiwa. Kebanyakan di antara latar belakang para penghafal al-Qur'an tersebut berasal dari pondok pesantren. ${ }^{7}$

Dengan berjalannya waktu dan zaman yang terus berkembang, banyak metode-metode tahfiz yang bisa digunakan dan diterapkan sesuai kemampuan yang ada. Akan tetapi dalam proses pengembangan tersebut hanya bersifat formalitas saja. Murid hanya disediakan dengan sedemikian target dan nilai yang ada, disibukkan akan pengaruh dunia, dihinggapi rasa malas dalam menghafal al-Qur'an atau beranggapan bahwa menghafal al-Qur'an adalah amalan seumur hidup yang dilakukan dalam proses penjagaannya. Apabila seorang menghafal al-Qur'an lalu ia lupa maka ia akan berdosa besar kepada Allah Swt. Dalam proses menghafal pun mereka terhalangi dengan angan-angan yang tidak baik atau faktor yang lain terkait metode yang bersifat monoton apabila ada yang mampu menghafal pun itu hanya sebatas hafal dalam fikiran tidak mengetahui tafsir dan maksud dari pesan-pesan terkandung dalam Al-Qur'an. Akibatnya, banyak di antara murid yang jenuh. Kurangnya dihiasi metode tersebut dengan penguatan mental dan juga metode yang tepat buat mereka. Kemudian, apabila seorang dia telah diberikan dorongan motivasi dan juga metode yang tepat buat diri mereka, maka apabila dalam proses menghafal mendapati sesuatu yang sulit dan jenuh ia akan tergerak dan cepat mengambil sikap melakukan sesuatu peregangan berfikir atau refreshing bermain yang dengannya itu apabila ia telah merasa senang dan terlepas dari rasa jenuh ia akan bersemangat lagi untuk memulai menghafal al-Qur'an. ${ }^{8}$

7 Pamungkas Stiyamulyani Pamungkas Stiyamulyani and Sri Jumini Sri Jumini, 'Pengaruh Menghafal Al-Qur'an Terhadap Highorder Thingking Skils (Hots) Ditinjau Dari Motivasi Berprestasi Mahasiswa', SPEKTRA : Jurnal Kajian Pendidikan Sains, 4.1 (2018), 25 <https://doi.org/10.32699/spektra.v4i1.43>.

${ }^{8}$ Jurnal Islamic and Education Manajemen, 'P-ISSN: 2541-383X e-ISSN: 2541-7088', 4.1 (2019), 25-38 <https://doi.org/10.15575/isema.v3i2.5255>. 
Hal demikian merupakan suatu koreksi tersendiri bagi kita sebagai seorang muslim yang ingin tahu isi dan kandungan alQur'an, sehingga mendorong Ustadz Yadi Iryadi, S.Pd. al-Hafiz untuk membuat metode penyempurnaan dari tiap metode yang ada yaitu metode yadain li tahfizil Qur'an yaitu metode tahfiz yang mengedepankan pengembangan imajinasi dalam proses penghayatan kandungan isi al-Qur'an. Walaupun belum bisa mahir dalam bahasa Arab, dibantu dengan literatur terjemah al-Qur'an, dan juga minim mampu membaca al-Qur'an. Maka mereka akan mampu menghafal al-Qur'an beserta mengetahui kandungan isi alQur'an sehingga yang diharapkan pesan-pesan yang terkandung dalam al-Qur'an sampai terhadap mereka dan mereka mengaplikasikanya dalam kehidupan mereka. Sehingga dalam kehidupan merekapun tampak nilai-nilai Islam.

Dalam penelitian ini penulis akan menjelaskan bagaimana implementasi akulturasi panca indera metode yadain dalam mengaktualisasikan potensi indera yang ada pada diri, dengan tujuan apa yang terkandung di dalam al-Qur'an berupa ajaranajaran Islam dapat tersampaikan dan mudah dipahami buat mereka yang menghafal al-Qur'an yang kemudian tidak lupa pula mengajarkan kepada manusia lainnya sebagai bentuk dakwah dalam diri kepada orang lain, sebagai bentuk syiar Islam menjadi agama rahmatan lil'alamin.

\section{Metode Penelitian}

Dalam metode penelitian ini diperlakukan sebuah pendekatan yang digunakan sebagai pijakan dari serangkaian pelaksanaan model pendekatan dalam penelitian. Dalam penelitian ini penulis gunakan model qualitative research yang bersifat deskripsi, yang menggunakan beberapa model pendekatan, di antaranya terjadi latar alamiah adapun secara istilah penelitian itu adalah instrumen atau beberapa data yang didapatkan dalam proses penelitian, kemudian data tersebut dianalisis secara induktif. Pendapat Robert dalam hal ini adalah penelitian yang berfokus 
dalam menjelaskan apa atau bagaimana yang terjadi. Penyusunan dalam proses pengambilan data dan penataan data bertujuan sebagai bentuk pertanggungjawaban penelitian. Dalam penelitian ini dihubungkan antara kesenjangan dalam antara ideologis dengan realita pada umumnya, yang data tersebut merupakan data yang valid dari hasil analisis penelitiannya. ${ }^{9}$

Moleong berpendapat bahwa penelitian fenomologi dalam hal ini ialah mempunyai makna upaya pemahaman atas suatu peristiwa yang terjadi pada suatu masa/keadaan yang terjadi pada saat itu. Penelitian dalam hal ini fokus terhadap apa-apa yang terjadi pada saat di lapangan ialah pada pelaksanaan metode yadain li tabfiril Qur'an. Target dalam fokus penelitian ini adalah implementasi metode yadain oleh peserta karantina tahfiz di Yayasan Karantina Tahfiz Nasional Kab. Kuningan. Dalam penjelasan di atas dapat diambil kesimpulan bahwa penelitian yang menggunakan dasaran fenomenologi dapat diukur dengan kebenaran empiris sensoris yakni kebenaran empiris sensoris, empiris masuk akal, empiris etika dan empiris transendental.

Berdasarkan empat kebenaran di atas dalam hal ini peneliti mencari empat kebenaran yang menjadi langkah dalam proses penelitian yaitu masuk akal/logis, bagus/etic, dan transendental. Hal ini akan menuntun peneliti akan memberi makna setiap fenomena yang terjadi saat berlangsung penelitian. ${ }^{10}$

Kemudian maksud dari diadakanya penelitian kualitatif ini adalah untuk mengemukakan pemahaman yang masuk akal dari permasalahan yang diteliti. Dengan menggunakan teknik hasil observasi, wawancara, dokumentasi merupakan data utama peneliti

${ }^{9}$ Ali Akbar and Hidayatullah Hidayatullah, 'Metode Tahfidz Al-Qur'an Di Pondok Pesantren Kabupaten Kampar', Jurnal Ushuluddin, 24.1 (2016), 91 $<$ https://doi.org/10.24014/jush.v24i1.1517>.

${ }^{10}$ Dewi Maharani and others, 'Pelatihan Komputer Dalam Meningkatkan Tahfidz Qur'an Menggunakan Al-Qur'an Digital Tajwid', Jurdimas (Jurnal Pengabdian Kepada Masyarakat) Royal, 1.2 (2018), 95-100 <https://doi.org/10.33330/jurdimas.v1i2.120>. 
yang kemudian dilakukan sebuah analisis mendalam dari narasumber yakni Ustadz Yadi Iryadi dan juga peserta karantina tahfiz. Selanjutnya diinterpretasikan berdasarkan tujuan dan permasalahan yang terjadi sehingga penelitian ini dilakukan.

Adapun tempat diadakanya penelitian ini adalah bertujuan untuk pengambilan data dari informasi di lapangan yang diperlukan peneliti sebagai fokus pemecahan permasalahan berdasarkan kaedah yang ada. Adapun tempat diadakanya penelitian ini adalah Yayasan Karantina Tahfiz Nasional yang bertempat tepatnya Jalan Baru Obyek Wisata di Cibulan adapun desanya yaitu di Maniskidul kemudian Kecamatan Jalaksana terletak di kabupaten Kuningan yaitu Provinsi Jawa Barat. ${ }^{11}$

Yayasan Karantina Tahfiz Nasional tersebut penulis pilih adakan penelitian dikarenakan terdapat progam akselesarasi li tabfiqil qur'an yang juga membentuk moral dan etika keislaman, pembiasaan diri yang diterapkan dalam bingkai etika yang santun, mempunyai keimanan yang kuat, taat agama, dan juga terdapat progam utama yaitu tahfiz akselerasi. Progam akselerasi yang dimaksud adalah progam menghafal al-Qur'an dalam kurun waktu 30 hari atau lebih dikenalnya one day one juz yaitu satu hari satu juz yang menggunakan teknik atau metode yadain.

Dalam hal ini membuat peneliti tertarik dengan adanya progam menghafal al-Qur'an yang dilakukan dalam waktu yang singkat namun masih mengindahkan/memperhatikan tajwid. Adapun bentuk kegiatan ini adalah mubafidz/mubafidzah mengadakan taklim atau pembelajaran mengenai al-Qur'an sesuai apa yang mereka butuhkan, serta membantu dalam pengajaran berupa diperdengarkan bacaan ayat yang sulit/sukar apabila dibutuhkan oleh peserta menghafal dengan tetap memperhatikan kaedah-kaedah umum tajwid dalam membaca dan menghafal alQur'an. Dan juga memberikan contoh pembiasaan yang baik

11 Maniskidul Kuningan and others, '( Implementasi Program Karantina Sebulan Hafal Al-', 4.2 (2019).

344 | TAJDID vol. 20, No. 2, Juli - Desember 2021 
mengenai senantiasa mulazamah atau berinteraksi dengan al-Qur'an serta tidak lupa pula mengaplikasikan dalam kegiatan sehari-hari perintah yang terkandung di dalamnya.

\section{Pembahasan}

\section{Akulturasi Panca Indra Metode Yadain Li Tahfizil Qur'an}

1. Akulturasi

Secara bahasa akulturasi ialah proses atau hasil pertemuan kebudayaan atau bahasa di antara anggota dua masyarakat bahasa, ditandai oleh peminjaman atau bilingualisme. Adapun secara istilah yang dimaksud akulturasi ialah proses pengasahan atau pengoptimalisasian belajar melalui kompetensi yang ada dalam diri berupa pemaksimalan proses belajar dari panca indera yang ada yang dapat digunakan dalam proses belajar.

2. Panca Indera

Secara bahasa ialah sistem fisiologi dalam tubuh manusia untuk mengenali, merasakan, dan merespon terhadap serangkaian stimulus secara fisik. Saat suatu indera mengenali atau merasakan sesuatu, indra akan mengumpulkan informasi untuk nenberikan persepsi dan respon terhadap apa yang diketahui dari lingkuang sekitar. Adapun secarah istilah yang dimaksud dari panca indera adalah proses aktualisasi panca indera yang berada dalam diri yang kemudian digunakan dalam proses menghafal.

3. Metode Yadain

Metode yadain ialah asal kata dari "yadain" yaitu secara bahasa memiliki arti يَد artinya tangan, yadain يَدَيْن artinya dua tangan, hal ini semakna atau filosofi penamaan dari metode yadain tersebut diambil dari penggagas atau penemu metode yadain yaitu Ustadz Yadi Iryadi. 
Adapun secarah istilahnya metode yadain li tabfiəil Qur'an adalah sebuah metode akselerasi yang bertujuan untuk memudahkan seseorang dalam menghafal al-Qur'an dengan tujuan untuk menjaga dan menghafal ayat al-Qur'an dengan mengetahui cara baca ayat Al-Qur'an, dan refleksi gerakan tangan dengan menggunakan visualisasi tadabur al-Qur'an bagian kiri dan kanan. Adapun kiri menunjukkan suatu hal yang tidak baik, semisal orang yang dia sengaja mengingkari kebenaran Islam maka ia akan merugi kehidupanya di dunia dan di akherat. Sedangkan kanan ditujukan pada sesuatu yang baik, contohnya mengetahui segala sesuatu kenikmatan yang Allah Swt. berikan kepada orang beriman kelak ia akan dimasukkan kedalam surga.

Manfaat dalam penerapan metode yadain adalah mampunya seorang penghafal tersebut mengetahui letak ayat dan nomor ayat atau yang bisa disebut (visualisasi al-Qur'an), kemudian mampunya penghafal tersebut mentadaburi apa yang berada dalam isi kandungan ayat al-Qur'an sehingga pesanpesan yang berada dalam al-Qur'an tersebut dapat tersampaikan padanya melalui perenungan ayat al-Qur'an dengan dibantu terjemah Kementrian Agama Republik Indonesia, sehingga harapannya dapat bertambah rasa takutnya kepada Allah Swt. ${ }^{12}$

Sebelum mempelajari tentang metode Yadain li Tabfizil Qur'an alangkah baiknya kita mengevaluasi mengapa metode menghafal al-Qur'an yang telah ada sebelumnya tidak selalu cocok bagi sebagian orang namun berhasil oleh sebagian lainnya. Bisa diasumsikan bahwa hal itu disebabkan adanya perbedaan pada setiap orang dalam memproses suatu informasi agar masuk kedalam memori permanennya.

12 Ari Prayoga and others, 'Manajemen Pembelajaran Tahfidzul Quran Berbasis Metode Yaddain Di Mi Plus Darul Hufadz Sumedang', Nidhomul Haq: Jurnal Manajemen Pendidikan Islam, $4.2 \quad$ (2019), 140-56 <https://doi.org/10.31538/ndh.v4i2.326>.

346 | TAJDID vol. 20, No. 2, Juli - Desember 2021 
Informasi masuk ke otak melalui panca indera, ini telah kita ketahui. Masing-masing orang didominasi oleh kemampuan indera tertentu. Dominasi kemampuan indera dalam proses belajar ialah dominasi visual atau penglihatan, auditorial atau pendengaran, kinestetik atau gerakan, olfactory atau penciuman, dan gustatory atau pengecapan. ${ }^{13}$

Jika semua indera kita normal, bisa dipastikan kita mempunyai lima fungsi tersebut tapi dengan dominasi yang berbeda-beda. Dengan demikian bisa memilih cara menghafal al-Qur'an sesuai dominasi gaya belajarnya.

\section{Li Tabfiril Qur'an}

Tahfiz berasal dari kata haffąha-yubaffirhu-tahfizhan yang mempunyai arti menghafal dikarenakan terdapat "tasydid" pada fa' fi'il madhiyah dan mudhari'-nya. Adapun kata "menghafal" berasal dari kata "hafal" yang padanya terdapat dua makna yaitu: (1) masuknya hafalan atau pengetahuan ke dalam ingatan.

Dan (2) kemampuan mengucapkan ulang hafalan (tanpa adanya media dalam membantu ingatanya). Suryadi Suryabrata berpendapat dalam hal ini bahwasanya kegiatan mengingat hafalan/pengetahuan merupakan sebuah aktivitas menancapkan hafalan atau pengetahuan dalam sistem otak dengan sadar dan sengaja yang dilakukan secara bersungguhsungguh. ${ }^{14}$ Dari penjelasan di atas dapat kita simpulkan bahwasanya kegiatan menghafal merupakan aktivitas yang menggunakan daya ingat dalam menyimpan atau mengahafal sesuatu dalam diri manusia yaitu otak. Yaitu dengan cara melaui panca indra, kemudian dilakukan pengulangan ucapan beberapa kali tanpa menggunakan media atau buku dalam proses mengingat apa yang telah dihafal. Adapun secara istilah yang dimaksud dengan "Tabfizul Qur'an" ialah proses menghafal al-Qur'an secara berurutan menurut tata letak yang

\footnotetext{
${ }^{13}$ Kuningan and others.

14 'Kamus Mahmud Yunus.Pdf.
} 
telah disepakati oleh para ulama. Qurra' yang terdapat dalam mushaf atau lembaran-lembaran al-Qur'an "Utsmani”" yang diawali surah al-Fatihah kemudian diakhiri pada surat al-Nas yang dinilai sebagai salah satu bentuk ibadah apabila menghafal dan menjaga al-Qur'an. Menjaga isi al-Qur'an baik secara lafal dan juga arti merupakan suatu kewajiban bagi umat islam dalam menjaga kemurnianya dari mulai diturunkanya al-Qur'an melalui perantara malaikat Jibril hingga sampai pada umat manusia akhir zaman saat ini yang umur kaum muslimin telah mencapai $1443 \mathrm{H}$ dari pengutusan Nabi Muhammad saw. ${ }^{15}$

\section{Tahsin, Tajwid, dan Makharijul Huruf}

Istilah tahsin ialah berasal dari kata bahasa Arab yang berbentuk تحسين, yang mempunyai arti membaguskan, meningkatkan, mempertajam, mengasah, mengindahkan. Adapun secara istilah tahsin adalah membaguskan bacaan alQur'an menurut kaedah-kaedah ilmu tajwid yang berlandaskan pada pengajaran dari Rasulullah saw. untuk menjaga keotentikan baik lafal dan juga makna yang terkandung dalam al-Qur'an sehingga harus benar-benar dijaga sesuai dari yang dicontohkan Nabi Muhammad saw.

Adapun tajwid menurut istilah dalam bahasa Arab ialah تجويد, berasal dari kata جوّد-يجوّد-تجويدا (jawwada) secara bahasa mempunyai arti bagus, indah, elok, atau bisa membaguskan. Adapun istilah dari Ilmu Qiraah ialah tajwid mempunyai arti mengeluarkan huruf pada tempatnya di mana ia keluar disertai dengan pemberian sifat-sifat yang dimiliki dari huruf tersebut. Dari pengertian di atas kita ketahui bahwasanya ilmu tajwid adalah disiplin ilmu yang mempelajari padanya kaedah-kaedah cara membaca al-Qur'an, bagaimana mengucapkan hurufhurufnya disertai dengan hukum bacaan tajwidnya semisal

${ }^{15}$ Nurul Hidayah, 'Strategi Pembelajaran Tahfidz Al-Qur'an Di Lembaga Pendidikan', Ta'allum: Jurnal Pendidikan Islam, 4.1 (2016), 63-81 <https://doi.org/10.21274/taalum.2016.4.1.63-81>. 
panjang dan pendeknya, cara berhenti ketika waqaf dan ibtida' dan lain sebagainya.

Adapun istilah makharijul buruf / مخارج الحروف dibsini ialah tempat-tempat keluarnya huruf dengan diikuti sifatnya sehingga lantunan ayat al-Qur'an tersebut bisa terdengan fasih, lembut dan indah tanpa diikuti atau tercampur dengan lagham/dialek atau logat dari sebuah daerah, sehingga benarbenar keluarnya bacaan ayat al-Qur'an.

6. Al-Hafir, Hafiz dan Hamilul Qur'an

Istilah al-hafidz, atau hafiz. al-Qur'an ialah gelar yang dinisbatkan atau dilabelkan kepada penghafal al-Qur'an yang telah menyelesaikan hafalannya secara kamil/sempurna yaitu 30 juz. Orang yang mampu menghafal al-Qur'an secara sempurna atau khatam maka ia sama halnya mampu mengingat baik secara pelafalan, tulisan, letak ayat dan juga nomor surat serta diiringi dengan kemampuan terjemah atau menghayati dari isi kandungan ayat el-Qur'an. Pada dasarnya al-hafiz ialah istilah atau gelar yang dinisbatkan kepada orang yang hafal hadis sebanyak 100.000 hadis dalam ingatanya diiringi dengan sanad atau mata rantai hadis serta matan atau isi hadis yang dalam hal ini tentunya al-Qur'an sudah lebih awal ia selesaikan. Namun berjalannya waktu al-hafiz, di Indonesia dinisbatkan gelar tersebut kepada penghafal al-Qur'an yang telah menyelasaikan hafalannya dengan baik dan sempurnya yaitu 30 juz.

حamilul Qur'an berasal dari bahasa Arab dari kata حمل يحمل. Sehingga hamilul Qur'an adalah orang yang membawa alQur'an dalam hafalannya. Orang hamilul Qur'an tidak pernah meninggalkan membaca, mempelajari, mengamalkan kitab suci al-Quran dalam keadaan apapun dan dibmana pun. Membaca dan mengkaji al-Qur'an adalah kebutuhan hidup bagi orang model ini.

7. Ziyadah dan Muraja'ah 
Istilah riyadah ialah asal kata dari bahasa Arab yang

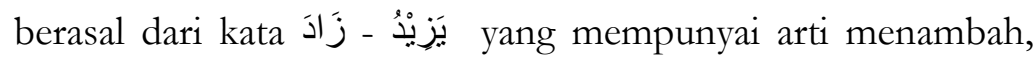
meningkatkan, menumbuhkan, memperbanyak, mempertinggi, memperbesar. Akan tetapi yang dimaksud ziyadah ialah menambah hafalan baru dari ayat suci al-Qur'an yang belum ia hafal.

Sedangkan muraja'ah ialah berasal daru kata رجعيرجع(raja'a-yarï'u) yang mempunyai arti mengulang, kembali, mengulas materi atau mengulang bacaan dari yang sebelumnya. Adapun secarah istilah muraja'ah ialah mengulang bacaan yang telah ia hafal dengan membaca kembali secara rutin beberapa kali sampai dirasa bacaan tersebut telah dianggap. Muraja'ah ialah amaliah terus menerus yang dilakukan oleh para penghafal al-Quran yang bertujuan agar hafalan senantiasa terjaga dan mendapatkan pahala dari setiap huruf yang dibaca, di samping itu juga bertujuan dalam rangka mendekatkan diri kepada Allah Swt.

\section{Syurutun Tahfizil Qur'an}

Menurut ahli pakar qira'at dalam hal ini yaitu Dr. Ahsin Wijaya dalam karanganya yang berjudul Bimbingan Praktis Menghafal Al-Qur'an, terdapat beberapa tahapan/syarat yang harus ditempuh terlebih dahulu sebelum memulai menghafal. Di antaranya ialah: 1) Fokus apa yang menjadi target dalam menghafal (mengosongkan pikiran dari pengaruh-pengaruh duniawi yang menjadi penghambat dalam proses menghafal al-Qur'an). 2) Ikblasun niyyah yaitu murninya niat hanya mengharap keridaan Allah Swt., tidak sedikitpun ditujukan pada pujian manusia. 3) Mempunyai tekad dan kesabaran yang kuat dalam proses menghafal al-Qur'an. 4) Istiqamah karena memang menghafal al-Qur'an dituntut untuk senantiasa bereaksi atau me-muraja'ah hafalannya. 5) Izin orang tua atas keinginan bahwasanya ingin menghafal al-Qur'an. Hal ini dilakukan mengingat bahwasanya doa dan restu orang tua sangatlah berpengaruh atas keberhasilan dan berkah atas izin Allah 
Swt. 6) Senantiasa menjauhkan diri dari perbuatan maksiat atau perbuatan yang tercela, dan mengamalkan isi al-Qur'an. ${ }^{16}$

\section{Memahami Gaya Belajar untuk Meningkatkan Potensi}

Kita semua tentu percaya bahwa pada dasarnya semua di antara manusia diciptakan secara unik mempunyai kemampuan dan kelebihan secara sendiri-sendiri walaupun lahir dalam keluarga yang sama. Itulah kenapa kakak dan adik dalam satu keluarga memiliki karakteristik yang berbeda. Begitu pula dengan cara merespon lingkungan luar. Sehingga, anak perlu menggali lebih dalam merespons untuk banyak hal di antaranya adalah mengetahui metode belajar yang pas untuk masing-masing anak.

Sebagian dari kita banyak cara seorang dalam proses menghafal al-Qur'an seperti halnya pasal dalam proses menghafal ia sangatlah cepat dan juga kuat hafalannya. Akan tetapi berbeda akan Adi yang ia dalam proses menghafal ia cepat namun juga cepat hilang hafalannya, dan masih banyak model menghafal lainnya, dan ada juga seorang yang dia model menghafalnya dengan versi irama yang ia dalam proses menghafalnya justrus dengan irama tersebut. Dalam sejatinya masing di antara diri manusia telah diberika Allah Swt. takaran kemampuan kecerdasan, namun dalam bidang yang manakah dan berbeda dominasi kecerdasanya. Gaya belajar adalah cara yang diambil oleh masing-masing orang dalam menyerap informasi baru dan sulit, bagaiamana mereka berkonsentrasi, memproses dan menampung informasi yang masuk ke dalam otak. Richard Bandler, John Grinder, dan Michael Grinder dalam karya mereka Neuro Linguistic Progamming (NLP) mengemukakan bukti kuat bahwa secara umum kita memiliki ciri

${ }^{16}$ D I Yayasan and others, 'Metode Pembelajaran Tahfid Zul Qur'an Di Yayasan Karantina Tahfid Zh Qur'an Nasional (Yktn) Salatiga Tahun 2019 Skripsi', 2019. 
belaja yang dominan yaitu karena memang menghafal al-Qur'an di tuntut untuk senantiasa bereaksi atau memuraja'ab hafalannya. ${ }^{17}$

\section{Macam Akulturasi Panca Indera Li Tahfizil Qur'an}

Menurut Bobbi De Poter dan Mike Hernacki secara umum gaya belajar dibedakan ke dalam tiga kelompok besar, yaitu gaya belajar visual, gaya belajar auditorial dan gaya belajar kinestetik. ${ }^{18}$

1. Dominasi Visual

Gaya belajar visual menitik beratkan pada ketajaman penglihatan. Artinya, bukyi-bukti kongkrit harus diperlihatkan terlebih dahulu agar mereka paham gaya belajar seperti ini yang mengandalkan penglihatan atau melihat dulu buktinya untuk kemudian bisa mempercayainya. Ada beberapa karakteristik yang khas bagi orang-orang yang menyukai gaya belajar visual ini. Pertama, melihat mushaf secara langsung, tahapan ini merupakan langkah awal dalam proses menghafal oleh hampir semua orang di antara kaum muslimin atau muslimat, karena langkah awal ini selain melihat maka akan diteruskan untuk dalam tahap pelafalan dari setiap ayat yang hendak dihafal. Jadi, dapat dipastikan bahwasanya melihat mushaf merupakan hal yang sangat penting untuk merekap tulisan dari sebuah ayat yang hendak dihafal. Kedua, menggunakan satu jenis mushaf, tidak mengganti model mushaf, trik atau cara ini memang terbukti manjur bagi para pemula dalam menghafalkan ayat al-Qur'an. Apabila dalam proses menghafalnya pun ia banyak berpindah mushaf alQur'an maka ia akan mengalami kesulitan dikarenakan kebingungan letak ayat tersebut, karena dari cetakan yang di Arab atau yang khat utsmani maka akan berbeda dengan tata letak yang berada di Indonesia. Ketiga, menghafal dengan

${ }^{17}$ Luk-Luk Nur Mufidah, 'Memahami Gaya Belajar Untuk Meningkatkan

Potensi Anak', Martabat: Jurnal Perempuan Dan Anak, 2017 <https://doi.org/10.21274/martabat.2017.1.2.245-260>.

${ }^{18}$ Mufidah.

352 | TAJDID vol. 20, No. 2, Juli - Desember 2021 
membuka dan menutup mushaf atau membuka al-Qur'an lalu memejamkan mata secara berulang sampai ayat yang hendak dihafal dapat ia lafalkan dengan melalui ingatan atau menutup al-Qur'an. Setelah itu, apabila telah diyakini lancar beberapa pengulangan tanpa melihat al-Qur'an maka selanjutnya dapat menyetorkan hafalannya kepada syaikh atau ustadz dan teman sejawatnya yang bacaannya telah baik. Keempat, mengamati tata letak setiap pergantian baris, ayat, dan pojok halaman, teknis atau cara ini bermanfaat kelak apabila ingin mengulang ayat atau surat maka ia akan segera menemukan ayat tersebut kemudian segera mengulang apabila dirasa kesulitan membaca atau dalam kondisi lupa sehingga membutuhkan untuk mebuka al-Qur'an. Kelima, saat terlihat imajinasi huruf-huruf al-Qur'an pada mushaf atau melayang, artinya dalam bacaan atau hafalan tadi dapat mempunyai gambaran abstraksi tentang ayat tersebut baik penulisan, maupun tata letak ayatnya. Keenam, alur cerita terbayang dalam imajinasi, otak seperti memutar film tentang kandungan ayat al-Qur'an saat tadabbur, sehingga di antara pesan-pesan yang terkandung dalam al-Qur'an berupa perintah-perintah ataupun larangan tersebut tersampaikan kepada pembaca dalam rangka meningkatkan iman dan mendekatkan diri kepada Allah Swt. Ketujuh, menghafal di tempat ramai bukan masalah karena fokus pada penglihatan, orang yang mempunyai gaya menghafal visual ia akan merasa biasa saja apabila menghafal al-Qur'an di tempat keramaian dan bukan menjadi masalah karena fokus ia pada apa yang ia lihat dan hafalkan. Kedelapan, saat membaca al-Qur'an biasanya cepat dan terkesan terburuburu. Hal ini bukan masalah karena masih bisa dilatih dengan tartil, dalam bacaan al-Qur'an. Ulama qurra' pun membagi dalam hal ini membaca al-Qur'an dibagi menjadi tiga bacaan yaitu: (1) al-Tahqiq ialah bacaan yang paling lambat atau biasa diiringi dengan lagham dalam membaca al-Qur'an tersebut; (2) al-Tadwir ialah bacaan al-Qur'an yang pertengahan atau sedang, 
tidak terlalu cepat dan juga tidak begitu lambat; dan (3) Hadr ialah bacaan cepat dalam melafalkan al-Qur'an dan biasanya model pembacaan seperti ini digunakan pada saat mengulang hafalan dalam jumlah yang banyak. Kesembilan, senang dengan warna-warni al-Qur'an, tidak merasa terganggu, karena hal tersebut merupakan bagian seni dalam sebuah warna yang enak dipandang yang dapat menjadikan seorang nyaman dengan berlama-lama bersama al-Qur'an.

Seorang yang dia itu model menghafalnya dengan visual lebih cepat menyerap bacaan al-Qur'an dan model penulisannya. Atau sama halnya tatkala ada ustadz/ustadzah menerangkannya di depan kelas baik dengan alat bantu tulisan, data, maupun gambar seorang yang visual ia akan lebih cepat menyerap. Di lingkungan rumah-rumah orang tua harus banyak memberikan stimulas berupa gambar-gambar yang bisa dilihat. ${ }^{19}$

2. Dominasi Auditori

Gaya belajar auditori (auditory learner) mengandalkan pada pendengaran untuk menghafal, memahami dan mengingatnya. Karakteristik model belajar/menghafal seperti ini akan benar-benar menempatkan pendengaran sebagai alat utama menyerap bacaan talaqqi dari seorang ustadz lalu ia hafalkan. Kita harus mendengar kemudian kita bisa mengingat dan mengulangi bacaan dari yang ustadz/ustadzah contohkan tersebut. Karakter pertama ialah lebih cepat hafal dengan talaqqi, diperdengarkan bacaan al-Qur'an, dengan memperdengarkan lantunan ayat al-Qur'an beberapa kali seorang yang dengan gaya menghafal auditori maka ia akan hafal hanya dengan mendengarkan ayat tersebut walaupun

19 Jamil Abdul Aziz, 'Pengaruh Menghafal Al-Quran Terhadap Pembentukan Karakter Peserta Didik Di Roudhotul Atfal (RA) Jamiatul Qurra Cimahi', Golden Age: Jurnal Ilmiah Tumbuh Kembang Anak Usia Dini, 2.1 (2017), 1$15<$ https://doi.org/10.14421/jga.2017.21-01>.

354 | TAJDID vol. 20, No. 2, Juli - Desember 2021 
tanpa melihat langsung ayat al-Qur'an. Kedua, biasanya suka meniru nada murattal syeikh tertentu dari Mp3, dengan seringnya memperdengarkan lantunan ayat al-Qur'an pada seorang syeikh atau qurra' al-Qur'an maka ia akan dengan mudah menirukan nada atau lagham dari bacaaan syaikh atau qurra' tersebut dengan beberapa lagham yang ia senangi. Ketiga, saat sendirian biasanya seperti mendengar suara murattal, keseharian dalam kehidupannya ia akan gunakan untuk mendengarkan lantunan bacaan syaikh yang ia sukai, biasanya dirinya lebih menghindari atau merasa tidak suka apabila ada seorang di sekelilingnya memainkan musik dengan keras bisa jadi dirinya akan mengingatkanya. Keempat, membaca menggunakan suara keras dengan tempo lambat (masalah ini bisa diatasi dengan latihan membaca cepat), seorang yang memiliki gaya menghafal auditori ia akan sering melatih suaranya dengan mencoba lagham dari syeikh yang dia sukai dengan bacaan yang santai atau lambat tujuannya dirinya agar dapat lebih menghayati dari bacaan tersebut. Kelima, saat tadabur ia seakan-akan mendengar kisah mengenai kandungan al-Qur'an, karena ia dalam menghafal sebelumnya terbantu denganya penguasaan bahasa al-Qur'an yaitu bahasa Arab atau dibantu dengan adanya terjemah al-Qu'an versi Kemenag di situ ia akan terbantu mengingat atau mentadaburi isi kandungan ayat al-Qur'an apabila ia membacakan atau mendengar ayat al-Qur'an. Keenam, merasa terganggu saat menghafal di tempat ramai, kecuali ramai karena bacaan alQur'an. Di sini ia akan merasa suka dan nyaman apabila dalam proses menghafal dalam keadaaan sendiri karena ia dapat fokus pada kemampuanya melalui bacaan al-Qur'an. Apabila dalam proses menghafal tersebut ia terdengar suatu keramaian dan lain-lain ia akan merasa terganggu. Seorang auditori ia dalam proses menghafal cenderung lebih dapat hafal dengan cara fokus terhadap apa yang dibacakan ustadz/ustadzah berupa lantunan ayat al-Qur'an yang hendak dihafal kemudian 
menirukan beberapa kali maka ia akan hafal baik dengan lantunan ayat al-Qur'an maupun dengan lagham/ mengindahkah bacaan.

3. Dominasi Kinestetik

Gaya belajar kinestetik mengharuskan individu yang bersangkutan menyentuh sesuatu yang memberikan kemudahan dan kenyaman dalam proses menghafal agar ia bisa mengingatnya. Tentu saja beberapa ada karakteristik model belajar seperti yang tak semua orang bisa melakukanya. Karakter pertama menghafal sambil berjalan-jalan atau sambil menggerakkan tangan dan kaki. Ini merupakan ciri unik dari seorang yang mempunya cara menghafal kinestetik. Dia akan senantiasa aktif dalam gerakan anggota tubuhnya yang dengan cara itu ia dapat menghafal al-Qur'an. Sangat berlainan dengan model menghafal visual maupun auditori yang dalam prses menghafalnya ia di tempat yang sunyi atau dalam kondisi sendiri. Kedua, menghafal dengan menunjuk-nunjuk seolah berbicara pada pelaku dalam kisah, jadi gerakan tersebut merupakan refleksi dari ayat yang ia hafal seakan akan ia terlibat dalam kisah tersebut. Menjadikan ia lebih dapat kbusyu' dalam proses menghafal ayat al-Qur'an. Ketiga, menunjuk huruf-huruf, pojok permulaan dan akhir ayat al-Qur'an, seagai bentuk penegasan apabila ia mengawali surat maupun ayat dan tanda selesainya bacaan suatu ayat yang padanya ia dapat menandainya berupa dalam bentuk gerakan menunjuk tangan tersebut. Keempat, saat membaca, yang terekam adalah gerakangerakan makharijul huruf dari setiap ciri khas sifat dan juga cara baca huruf atau ayat tersebut. Kelima, saat tadabur, ia sekanakan terlibat dalam alur kisah. Seolah menjadi pemeran utama dalam kisah mengenai kandungan al-Qur'an, dikarenakan ia dalam proses menghafal al-Qur'an aktif dan mentadaburinya dalam bentuk gerakan-gerakan yang menunjukkan ciri khas seorang kinestetik. Ke-enam, saat tadabur dan merasa menjadi pemeran utama, ia mampu merasakan sensasi haru, berharap, 
takut, dan berbagai efek perasaan lainnya seolah-olah ia mengalaminya sendiri. Dikarenakan ia dalam proses menghafal.

Seorang yang dengan gaya belajar seperti ini, ia dalam proses belajar maupun menghafal cenderung aktif bergerak, karena memang dalam proses menghafal atau belajarnya demikian.

\section{Dominasi Olfactori}

Gaya belajar olfactori biasanya dalam prose menghafal atau belajar ia mempunya karakteristik tertentu dalam keseharianya yang menjadikan ia merasa nyaman dengan aktivitasnya di antaranya ialah: pertama, biasanya sambil memegang mushaf dan menciumnya dengan hidung. Gerakan ini diinisiasikan dalam bentuk kecintaannya kepada al-Qur'an yang sebagai kalam Allah Swt. yang sebagai petunjuk bagi sekalian manusia. Kedua, memperhatikan bentuk mushaf dengan wangi-wangian, dengan corak warna mushaf yang menjadikan ia lebih nyaman dalam menghafal, atau dengan memberikan tanda-tanda ang unik sebagai bentuk kreasi ia dalam menghafal al-Qur'an. Ketiga, saat membaca yang terekam adalah imajinasi seakan merasakan harumnya surga atau baunya neraka. Seakan ia terlibat atau dapat merasakanya dalam menghayati al-Qur'an tersebut melalui bacaan ataupun hafalannya. Keempat, saat tadabur yang terasa adalah terlibat suasana dalam alur kisah, seolah itu benar terjadi pada dirinya, dari bacaan.

Seorang dengan gaya menghafal dan belajar seperti ini ia cenderung dapat merasakan dari apa yang ia fahami atau renungkan dalam isi al-Qur'an, merasa terlibat padanya alur cerita dalam al-Qur'an dan mempunya empati diri yang kuat atau perasa. 
5. Dominasi Gostatori

Gaya belajar gostatori biasanya dalam proses menghafal atau belajar ia mempunya karakteristik yang unik yaitu dengan menggunakan indera perasa yang berada pada mulut, dibantu dengan media penamaan buah, pohon atau hewan dan istilahistilah yang padanya tersebut ia akan mudah dalam proses menghafal dan belajar. Di antara karakteristik seorang yang dengan model menghafal atau belajar seperti itu adalah: pertama, menggunakan indera pengecapan secara imajiner. Membayangkan rasa dari setiap kata benda dan kata kerja yang dihafal dengan indah, sehingga terasa sensasinya. Kedua, merasakan panas atau dingin pada lidah. Kata-kata seperti kitab, petunjuk, orang bertakwa, alam gaib, salat, infaq atau beruntung mempunyai rasa yang berbeda di lidah atau indera pengecapan. Ketiga, imajinasi nyata ini menjadikan ayat lebih berkesan dan hidup di dalam tadabur makna.

Seluruh gaya belajar ini masuk dalam pikiran sadar dan bawah sadar manusia, sehingga cenerung menjadi memori permanen. Adapuan metode yang paling efektif dan terbaik adalah dengan mengoptimalkan segala panca indera yang ada pada diri. Metode yadain li tabfizil Qur'an dirancang untuk mengoptimalkan seluruh potensi indera manusia. Sehingga menghafal bukan hanya mengedepankan gaya visual, auditori, kinestetik, olfactori, kemudian gustatori yang berfokus pada satu kemampuan saja, namun juga secara keseluruhan kemampuan. Menurut pakar neuro linguistic progaming menjelaskan bahwa sub modality. Sedangkan sub modality adalah sebuah proses di mana gambaran dunia nyata digambarkan kembali pada pikiran manusia. ${ }^{20}$

\footnotetext{
${ }^{20}$ Kuningan and others.
}

358 | TAJDID vol. 20, No. 2, Juli - Desember 2021 


\section{Berlatih Imajinasi Tadabur Metode Yadain li Tahfizil Qur'an}

Sebelumnya, banyak yang mengira bahwa metode yadain dalam prakteknya menghafal gerakan tangan saja, namun hal demikian itu hanya sebagai proses awal saja, yang bertujuan untuk melatih tadabur dengan gaya visualisasi. Apabila seorang dapat memaksimalkan proses tadabur itu dengan baik maka gerakan yang diikuti dengan tangan itu tidak lagi dilakukan. Sama seperti roda bantu pada sepeda, jika pengendara sudah mahir dalam mengendarai sepeda maka roda bantu tersebut bisa dilepas dan digunakan kembali oleh orang yang ingin belahar naik sepeda. Oleh karena itu, gerakan tangan hanya untuk latihan imajinasi tadabur pada awalnya saja.

Cara berlatih tadabur ialah dengan cara melatih daya ingatan imajinasi kemudian membayangkan apa yang terdapat dalam kandungan menurut ayat al-Qur'an dengan jelas. Dapat disamakan dalam hal ini seorang yang dia membaca novel. Ayat-ayat yang terdapat dalam al-Qur'an dibaca kemudian dibayangkan dari hasil terjemahannya. Dalam proses menghafal, akan lebih baik apabila seorang tersebut melatih imajinasi atau gaya tadaburnya yaitu dengan cara berimajinasi/membayangkan, melihat, mendengar, meraba,dan juga rasa. Seperti halnya contoh apabila kita menyebut sebuah benda semisal "ayam" maka dalam bentuk nyatanya kita dapat membayangkan bentuk ayam tersebut dalam segala arah. Apabila kita mencoba membayangkan ayam tersebut pada posisi samping maka kita dapat membayangkan seketika itu pada arah tersebut, kemudian latihlah imajinasi tersebut para arah yang berbeda dari atas maupun bawah ataupun dari depan dan belakang sampai dapat gambaran atau imajinasi dari bentuk ayam tersebut pada empat dimensi. Dan juga bayangkan pula bentuk, warna dan juga bau dan rasanya.

Metode yadain ialah bertujuan agar orang yang menghafal alQur'an dapat memahami isi dan maksud apa yang terkandung dalam al-Qur'an meskipun dalam perjalananya belum menguasai 
metode bahasa Arab itu sendiri, yang terpenting adalah ia dapat membaca al-Qur'an dengan baik menurut kaedah ilmu tajwid yang dibantu al-Qur'an terjemah dalam proses tadaburnya. ${ }^{21}$

Tabel 1: Panduan Proses Menghafal

\begin{tabular}{|c|c|c|c|c|c|c|c|}
\hline No & Progam & $\begin{array}{l}\frac{\pi}{d} \\
\frac{\pi}{d} \\
2\end{array}$ & 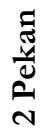 & $\stackrel{\frac{5}{7}}{\overparen{D}}$ & $\frac{\mathscr{J}}{3}$ & $\frac{\mathfrak{\pi}}{3}$ & 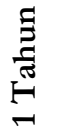 \\
\hline 2. & $\begin{array}{l}\text { Menelaah ilmu tajwid, } \\
\text { tahsin, makharijul huruf dan } \\
\text { talaqqi bacaan. } \\
\text { Gharib dan tasmi' hafalan } \\
\text { pada ustadz/muhafiz }\end{array}$ & $\checkmark$ & $\checkmark$ & $\checkmark$ & $\checkmark$ & $\checkmark$ & $\checkmark$ \\
\hline 3. & $\begin{array}{l}\text { Muraja'ah di setiap waktu } \\
\text { penguatan hafalan (pe- } \\
\text { mutqin-an) }\end{array}$ & $\checkmark$ & $\checkmark$ & $\checkmark$ & $\checkmark$ & $\checkmark$ & $\checkmark$ \\
\hline
\end{tabular}

\section{Definisi Tasmi'dan Mutqin}

Tasmi' berasal dari bahasa Arab yang asal katanya سمع يسمع (sami'a yasma'u). Tasmi yaitu memperdengarkan bacaan hafalan kepada sang guru atau teman secara bersamaan. Secara istilah dalam bidang menghafal al-Qur'an berarti memperdengarkan bacaan hafalan al-Qur'an di hadapan guru agar dikoreksi ketepatan dalam hafalan dan pengucapan.

Istilah mutqin ialah biasanya dilabelkan kepada para penghafal al-Qur'an yang sampai mempunyai kemampuan membacakan ayat

${ }^{21}$ Muhammad Iqbal Ansari, 'Pelaksanaan Karantina Tahfidzh Al-Qur'an 30 Hari Untuk Siswa Sekolah Dasar Dan Madrasah Ibtidaiyah Di Banjarmasin', Jurnal Madrasah Ibtidaiyah, 2.2 (2017), 1-18. 
al-Qur'an tanpa melihat atau membuka al-Qur'an secara terbuka atau dengan arti mempunyai kekuatan hafalan yang tsiqah/kuat. Adapun secara bahasa, mutqin ialah mempunyai arti kuat, membekas, melekat suatu dalam akal fikiran. Untuk menjadikan hafalan al-Qur'an senantiasa melekat atau membekas dalam akal fikiran memerlukan usaha yang kuat dan secara istiqamah mengulang hafalan biasanya dengan tingkat pengulangan 10 hingga 20 pengulangan hafalan dalam tiap ayat maupun halaman atau bahkan juz dengan tetap mengindahkan hukum tajwid dan juga makharijul hurufnya sehingga menjadi fasih dalam pengucapanya.

\section{Tabel Panduan dalam Menghafal Seluruh Ayat al-Qur'an}

Menghafal al-Qur'an merupakan amalan besar yang membutuhkan planning ke depan dalam mewujudkannya, dalam mewujudkannya tidak boleh asal dalam bertindak. Target dalam menghafal al-Qur'an pun harus jelas dan rinci, kapan harus menghafal dan kapan harus selesai. Dalam mewujudkan amalan besar tersebut baiknya tidak boleh ada kata penundaan, dalam hal ini apabila terdapat kesempatan dalam menghafal maka harus segera dijalankan jangan sampai waktu tersebut terlewatkan. Adapun target dalam mengkhatamkan al-Qur'an dalam hal ini tentunya disesuaikan dengan kemampuan yang ada dalam diri. Karena memang masing di antara diri seorang mempunyai kemampuan yang berbeda. Kapan harus memulai dan kapan dapat mengkhatamkanya 30 juz maka kitalah yang menentukan. ${ }^{22}$ Bisa jadi seorang menyelesaikannya dalam kurun waktu dua tahun, setahun, atau bahkan enam bulan dan satu bulan. Apabila target telah dapat diselesaikan dengan baik maka selanjutnya ialah menjadikan progam menghafal menjadi progam utama dalam hidup kita, artinya dalam proses menjalankannya membutuhkan

22 Rohmad Rohmad and Muslimin Muslimin, 'Tahfidz Al-Quran Dengan Metode Bil-Qolam Di Madrasah Tsanawiyah (Islamic Boarding School) AlAzhary Ajibarang Banyumas', MAGHZA: Jurnal Ilmu Al-Qur'an Dan Tafsir, 2.2 (2017), 91-99 <https://doi.org/10.24090/maghza.v2i2.1572>. 
prioritas yang lebih di antara yang lainnya bukan menjadi sampingan. Tujuan dalam penetapan target adalah agar dalam beraktivitas menghafal semakin jelas dan penggunaan waktu yang optimal. Sehingga dalam proses menghafal pun bisa khatam tepat waktu. Kalau pun dalam perjalanannya tidak sesuai dengan target maka ketidaksesuaian itu pun tidak terlampau jauh dari apa yang direncanakan dari awal karena memang penentuan target adalah hal yang sangat utama dalam keberhasilan progam. Dikarenakan seringnya rasa malas yang melanda para penghafal al-Qur'an dan apabila tidak mempunya target maka ia akan terlelap dalam kemalasan karena merasa tidak ada tuntutan dalam keseharianya. Tentu anda tidak ingin semangat menghafal al-Qur'an hanya di awal saja kemudian berhenti di tengah jalankan? ${ }^{23}$

Tabel 2: Panduan Target dalam Menghafal Seluruh Ayat al-Qur'an

\begin{tabular}{|c|c|c|c|c|c|c|c|}
\hline \multirow{2}{*}{$\begin{array}{c}\text { Jumlah } \\
\text { Hafalan } \\
\text { Setiap } \\
\text { Hari }\end{array}$} & \multicolumn{3}{|c|}{$\begin{array}{c}\text { Waktu yang Dibutuhkan } \\
\text { untuk Hafal Seluruh } \\
\text { Ayat al-Qur'an }\end{array}$} & \multirow{2}{*}{$\begin{array}{c}\text { Jumlah } \\
\text { Hafalan } \\
\text { Setiap } \\
\text { Hari }\end{array}$} & \multicolumn{3}{|c|}{$\begin{array}{c}\text { Waktu yang Dibutuhkan } \\
\text { untuk Hafal Seluruh } \\
\text { Ayat al-Qur'an }\end{array}$} \\
\hline & Tahun & Bulan & Hari & & Tahun & Bulan & Hari \\
\hline 1 ayah & 17 & 7 & 9 & 12 ayah & 1 & 5 & 15 \\
\hline 2 ayah & 8 & 9 & 18 & 13 ayah & 1 & 4 & 6 \\
\hline 3 ayah & 5 & 10 & 13 & 14 ayah & 1 & 3 & - \\
\hline 4 ayah & 4 & 4 & 24 & 15 ayah & 1 & 2 & 1 \\
\hline 5 ayah & 3 & 6 & 7 & 16 ayah & 1 & 1 & 6 \\
\hline 6 ayah & 2 & 11 & 4 & 17 ayah & 1 & - & 10 \\
\hline 7 ayah & 2 & 6 & 3 & 18 ayah & - & 11 & 19 \\
\hline 8 ayah & 2 & 2 & 12 & 19 ayah & - & 11 & 1 \\
\hline 9 ayah & 1 & 11 & 12 & 20 ayah & 3 & 4 & 24 \\
\hline
\end{tabular}

${ }^{23}$ Imam Mashud, 'Meningkatkan Kemampuan Dalam Setoran Hafalan AlQur'an Melalui Metode Talaqqi Pada Siswa Kelas Vib Sekolah Dasar Islam Yakmi Tahun 2018', NATURALISTIC: Jurnal Kajian Penelitian Pendidikan Dan Pembelajaran, 3.2 $<$ https://doi.org/10.35568/naturalistic.v3i2.397>. 


\begin{tabular}{|l|c|c|c|c|c|c|c|}
\hline 10 ayah & 1 & 9 & 3 & 21 ayah & 1 & 8 & 12 \\
\hline 11 ayah & 1 & 7 & 6 & 22 ayah & - & 10 & 6 \\
\hline
\end{tabular}

Untuk memotivasi diri, buatlah target 30 juz, jangan setengah-setengah. Tempelkan tulisan sesuai target anda di dinding kamar tidur atau tempat lain yang biasa dilewati dan dilihat. Seperti tulisan "Tahun depan saya harus hafal 30 juz", atau "Bulan depan saya harus hafal 30 juz" atau dengan kata-kata semisalnya. Dengan kata-kata motivasi tersebut, anda akan lebih terdorong dan selalu bersemangat lalu segera menyelesaikan hafalan. Dalam membuat target tentu saja harus disesuaikan dengan realitas kemampuan, target sebaiknya dibuat sesuai acuan kemampuan otak. Anda bisa membuat progam tahunan, bulanan, mingguan atau harian sesuai kemampuan pada diri. Karena dengan adanya target proses menghafal akan lebih terencana dan hasilnya sesuai harapan. Untuk memaksimalkan target yang anda buat, adakan evaluasi. Jika targetnya mingguan maka evaluasi bisa dilakukan setiap hari. ${ }^{24}$

\section{Efektivitas Metode Yadain Li Tahfizil Qur'an}

Hukum mempelajari din al-islam dalam hal ini bagi pemeluk Islam adalah wajib mempelajari bagaimana mentauhidkan atau mengesakan Allah Swt. dengan sebenar-benarnya tanpa adanya penyampuran keyakinan pada selainnya. Kemudian mempelajari syariat-syariatnya yang dalamnya terdapat hudud/batasan-batasan yang berupa perintah-perintah Allah Swt. dan juga laranganlarangan Allah Swt. Ini semua dapat kita pelajari dan pahami oleh umat muslim yaitu dengan mempelajari al-Qur'an sebagai petunjuk dan juga pedoman umat manusia. Di antara ikhtiyar atau usaha dalam hal ini adalah dengan menghafal al-Qur'an beserta makna yang terkandung dalam al-Qur'an dengan menggunakan metode

${ }^{24}$ Moh Rijal Mustaqim and Hanifah Nurhaedha, 'Management of Halaqah Tahfidz Al-Qur'an in Darut Taqwa Ponorogo Islamic Boarding School', Jurnal Tarbiyatuna, 11.2

(2020), $128-42$ <http://journal.ummgl.ac.id/index.php/tarbiyatuna/article/view/3040>. 
yadain yaitu menghafal al-Qur'an dengan diiringi membaca terjemah al-Qur'an dan juga pembelajaran mengenai tafsir alQur'an dan sunah. Metode yadain dalam hal ini yang dimaksud ialah mendorong para penghafal al-Qur'an tersebut dalam proses menghafal al-Qur'an mengaplikasikan panca indera yang ada pada diri, baik dengan visual, auditori, kinestetik, olfactori dan gostatori, hanya dengan bermodal penguasaan ilmu tajwid dan terjemah alQur'an. $^{25}$

Hukum menghafal ayat al-Qur'an ialah fardhu kifayah yang artinya apabila sebagian kaum muslimin telah melakukan menghafal al-Qur'an maka gugurlah kewajiban muslim yang lainnya menghafal al-Qur'an, tidak sampai jatuh pada dosa karena telah terwakilkan pada kaum muslimin yang telah menghafalnya. Akan tetapi, menurut Imam al-Suyuthi, menghafal al-Qur'an hukumnya fardhu 'ain. Beliau berpendapat seperti itu dikarenakan supaya tidak adanya penyimpangan terhadap al-Qur'an. Dan hukum mengajarkan al-Qur'an sendiri ialah fardhu kifayah yang dalam hal ini merupakan bentuk amalan yang paling utama untuk mendekatkan diri kepada Allah Swt.

Adapun orang yang telah hafal al-Qur'an maka mempunyai kewajiban untuk senantiasa mengulang dan menjaga hafalannya. Adapun kodrat dari manusia sendiri diciptakan ialah di antara salah dan lupa dan sebaik-baik kesalahan ialah yang mau memperbaiki diri dan taubat. Hal ini semakna dengan "Inna al-insan maball alkhatha' wa nisyan", yang berarti sesungguhnya manusia itu tempatnya salah dan lupa. Secara hukum apabila dalam penjagaannya ia telah berikhtiyar namun apabila ada yang lupa di luar dari batas kemampuan maka hal ini dimaafkan atau tidak berdosa. Namun menurut hadis Nabi, hukum memelihara dan menjaga al-Qur'an yaitu fardhu 'ain atau wajib sebagaimana bunyi dalam hadis Nabi Muhammad saw. yaitu: "Jagalah al-Qur'an ini,

${ }^{25}$ Jurnal Islamic and Education Manajemen, 'P-ISSN: 2541-383X e-ISSN: 2541-7088, 6.1 (2021), 47-54.

364 | TAJDID vol. 20, No. 2, Juli - Desember 2021 
demi Dzat yang jiwaku berada dalam tangan-Nya, sesungguhnya dia lebih mudah terlepas dari pada tali kekang onta." Dan yang paling penting dalam hal ini ialah al-Qur'an harus dipelajari, dipahami, dijaga, dan diamalkan serta didakwahkan. Karena barangsiapa yang menghafal, mempelajari al-Qur'an lalu ia mengamalkan dalam kehidupannya, maka al-Qur'an akan dapat menjadi syafaat atau bujjah sebagai penolong kelak di akherat yang akan menyelamatkanya di hadapan Allah Swt. Sebagaimana dalam hadis yang berbunyi, "Dan al-Qur'an akan menjadi bujjah bagimu (membela dan menolong) atau juga bisa al-Qur'an dapat menjadi bujjah atasmu (mengancam/menjerumuskan) jika mengetahui kebaikan syariatnya dilanggar atau tidak dijalankan." (HR. Muslim) $)^{26}$

\section{Kelebihan dan Kekurangan Metode Yadain Li Tahfizil Qur'an}

\section{Kelebihan Metode Yadain Li Tabfizil Qur'an}

Metode yadain dalam hal ini merupakan metode dari penyempurna metode-metode sebelumnya seperti halnya metode talaqqi, metode taqril, metode tasmi' dan lain sebagainya yang semuanya itu dirumuskan menjadi sebuah metode penyempurnaan yang bertujuan agar penghafal al-Qur'an dapat menghafal al-Qur'an dengan mudah, cepat, bertajwid dan masih mengindahkan sisi tadabur dan pesan yang terkandung di dalam ayat-ayat suci al-Qur'an. Di antara kelebihan metode yadain apabila diterapkan dalam proses menghafal ialah sebagai berikut. $^{27}$

Dari hasil penelitian yang peneliti adakan penghafal alQur'an apabila menerapkan metode yadain dalam proses menghafal al-Qur'an ialah hafalan lebih kuat dan membekas

26 Dimensi-dimensi Psikologis Tahfidz Al- Qur and others, 'Jurnal Intelegensia - Vol. 04 No. 2 Juli-Desember 2016 | 78', 04.2 (2016), 78-112.

27 Al-muhsin I I Dalam, Menumbuhkan Minat, and Tilawatil Quran, 'PISSN: 2541-383X e-ISSN: 2541-7088', 6.1 (2021), 25-36. 
dalam ingatan. Diibaratkan mengukir di atas batu hal ini memang terbukti dalam proses menghafalnya pun sebelumnya ia harus mempelajari dan memahami redaksi dari ayat yang hendak ia hafalkan sehingga apabila ia telah selesai menghafal dan memuraja'ah maka apabila mengulang di ayat yang pernah ia hafal ia akan teringat dengan isi ataupun redaksi dari ayat alQur'an tersebut.

Menurut observasi di lapangan pada umumnya sebagian penghafal al-Qur'an ia hanya lewat begitu saja di bibir, tanpa adanya sisi bekas, perasaan yang diikuti rasa takut kepada Allah Swt. dikarenakan apa yang ia hafal hanya sebatas ejaan kata ataupun lantunan yang hanya berhenti di lisan tanpa diiringi dengan tadabur atau menghayati al-Qur'an. Sehingga dalam hal ini metode yadain li tahfiril Qur'an ini menuntut agar orang yang mau menghafal al-Qur'an tersebut supaya membaca minimal terjemah dari ayat yang ia hendak mau hafalkan terlebih lagi apabila punya kemampuan berbahasa Arab maka hal ini menjadikan nilai berharga dalam mentadaburi isi ayat al-Qur'an dalam rangka mendekatkan diri kepada Allah Swt.

Metode yadain li tahfiril Qur'an dalam hal ini metode yang mendorong para penghafal al-Qur'an mengaktualisasikan seluruh potensi diri dalam menghafal al-Qur'an. Sehingga dalam proses menghafal al-Qur'an dapat lebih cepat, nyaman, baik dan efisien serta dapat terjangkau baik dari kalangan anakanak maupun dari kalangan remaja bahkan ortua, dengan menggunakan gaya menghafal visual (membaca), auditory (talaqqi), kinestetik (gerakan-gerakan/memperagakan hasil dari ekspresi menghafal al-Qur'an, olfactori (penciuman), gustatori (perasa) yang masing-masing ini berada pada diri manusia.

Dalam penerapan metode yadain li tabfizil Qur'an ini mendorong para penghafal al-Qur'an agar tetap berkonsentrasi memperhatikan ilmu tajwid dalam proses menghafal, sebelum menghafal ia harus dipastikan sudah khatam atau mahir ilmu 
tajwid. Sehingga dalam proses menghafal al-Qur'an pun ia berkewajiban menghafal al-Qur'an dengan mempraktikkan ilmu tajwid yang ia sudah pelajari.

Tujuan diadakanya metode yadain li tahfizil Qur'an ialah salah satu bentuk usaha mempelajari dan memahami al-Qur'an yang di dalamnya terdapat hukum-hukum Allah Swt. sehingga umat Islam seluruh dunia berkewajiban mempelajari isi alQur'an hal ini sesuai dengan hadis yang disampaikan oleh Rasulullah saw. yang beredaksi: "Ada tiga ilmu yang harus dipelajari oleh semua yang mengaku beriman/menyembah Allah Swt. yaitu ilmu al-Qur'an, sunah Nabi Muhammad saw. yang menjadi bayan atau penjelasan dari al-Qur'an dan yang ketiga adalah faraid ialah ilmu waris yang mempelajari tentang hak waris yang sudah diatur oleh Allah Swt. ${ }^{28}$

\section{Kekurangan Metode Yadain Li Tabfizil Qur'an}

Segala sesuatu metode yang ada dalam menghafal alQur'an dalam hal ini mempunyai sisi positif dan negatif tidak terkecuali yaitu metode yadain li tabfiril Qur'an. Dalam hal ini juga mempunyai sisi kekurangan di antaranya sebagai berikut.

Seorang yang ia mempunyai gaya menghafal sendiri apabila dihadapkan dengan metode yang baru (metode yadain) dalam hal ini ia akan merasa kesulitan atas adaptasi atau hal-hal baru yang ia belum terbiasa padanya. Seperti halnya pembacaan ayat al-Qur'an oleh seorang guru kepada murid dari ayat yang hendak dihafal maka ia akan merasa jenuh, tidak nyaman dan lain sebagainya, dan mempunyai anggapan bahwasanya ia mampu dan lebih baik namun kenyataan sebenarnya masih ada yang perlu dibenahi. ${ }^{29}$

\footnotetext{
28 Tarbiyah and others.

${ }^{29}$ Islamic and Manajemen, 'P-ISSN: 2541-383X e-ISSN: 2541-7088'.
}

TAJDID vol. 20, No. 2, Juli - Desember 2021 | 367 
Gambar 1: Skema Penerapan Metode Yadain Li Tahfizil Qur'an

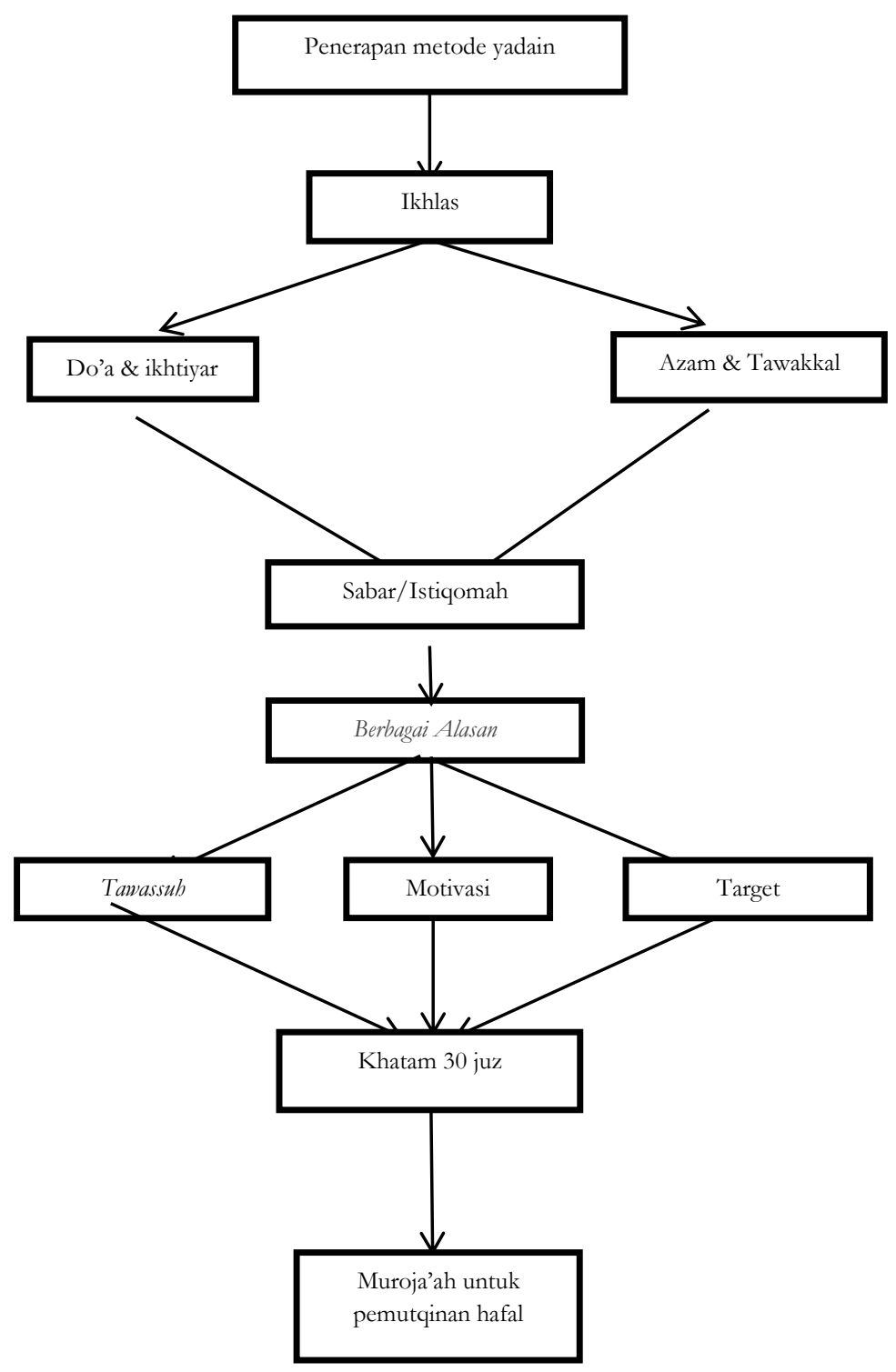




\section{Penutup}

Berdasarkan penjelasan di atas dapat disimpulkan bahwasanya kemudahan dalam proses menghafal al-Qur'an terletak pada pengenalan pada kemampuan dalam diri, di mana ia dapat mengoptimalkan segala kemampuan yang ada dalam diri yaitu dalam menghafal al-Qur'an. Sehingga dengan pengenalan dan pengaplikasian panca indera semua maka akan memberikan kemudahan dalam menghafal al-Qur'an. Ditunjang dengan sebuah metode yang di situ menjadi sebuah kendaraan/jalan dalam proses menghafal al-Qur'an. Akulturasi panca indra metode yadain ini merupakan sebuah metode terkini, yang dalam proses menghafal al-Qur'an dengan baik yang tetap mengindahkan sisi tercapainya pesan-pesan yang terkandung dalam al-Qur'an. Metodenya pun dapat dijangkau oleh semua kalangan baik untuk anak, dewasa, maupun di usia lanjut. Karena memang metode yadain ini adalah metode mutakhir yang menjadi penyempurna metode-metode sebelumnya. Metode yadain menggunakan seluruh panca indera yang ada pada diri, mengaktualisasikan semua indera dalam proses menghafal dan mengajak kepada para penghafal untuk memahami isi kandungan, kisah dan perintah serta larangan apa yang ada di dalam al-Qur'an dapat tersampaikan kepada penghafal al-Qur'an melalui membaca terjemah ayat yang hendak dihafal.

\section{Daftar Pustaka}

Akbar, Ali, and Hidayatullah Hidayatullah, 'Metode Tahfidz AlQur'an Di Pondok Pesantren Kabupaten Kampar', Jurnal Ushuluddin, 24.1 (2016), <https://doi.org/10.24014/jush.v24i1.1517>

Aziz, Jamil Abdul, 'Pengaruh Menghafal Al-Quran Terhadap Pembentukan Karakter Peserta Didik Di Roudhotul Atfal (RA) Jamiatul Qurra Cimahi', Golden Age: Jurnal Ilmiah Tumbuh Kembang Anak Usia Dini, 2.1 (2017), 1-15 <https://doi.org/10.14421/jga.2017.21-01>

Dalam, Al-muhsin I I, Menumbuhkan Minat, and Tilawatil Quran, 
'P-ISSN: 2541-383X e-ISSN: 2541-7088', 6.1 (2021), 25-36

Fachrudin, Yudhi, 'Pembinaan Tahfizh Al-Quran Di Pesantren Tahfizh Daarul Qur'an Tangerang', Kordinat: Jurnal Komunikasi Antar Perguruan Tinggi Agama Islam, 16.2 (2017), 325-48 $<$ https://doi.org/10.15408/kordinat.v16i2.6445>

Hidayah, Nurul, 'Strategi Pembelajaran Tahfidz Al-Qur'an Di Lembaga Pendidikan', Ta'allum: Jurnal Pendidikan Islam, 4.1 (2016), 63-81 <https://doi.org/10.21274/taalum.2016.4.1.63-81>

Islamic, Jurnal, and Education Manajemen, 'P-ISSN: 2541-383X eISSN: 2541-7088’, 3.2 (2018), 220-30 'P-ISSN: 2541-383X e-ISSN: 2541-7088', 4.1 (2019), 25$38<$ https://doi.org/10.15575/isema.v3i2.5255> 54

'Kamus Mahmud Yunus.Pdf'

Kuningan, Maniskidul, Jawa Barat, Metode Yadain, Li Tahfizh, Dudung Abdul Karim, Hafid Nur Muhammad, and others, '( Implementasi Program Karantina Sebulan Hafal Al-', 4.2 (2019)

Maharani, Dewi, Fauriatun Helmiah, Ricky Ramadhan Harahap, and Barany Fachri, 'Pelatihan Komputer Dalam Meningkatkan Tahfidz Qur'an Menggunakan Al-Qur'an Digital Tajwid', Jurdimas (Jurnal Pengabdian Kepada Masyarakat) Royal, $\quad 1.2 \quad$ (2018), 95-100 <https://doi.org/10.33330/jurdimas.v1i2.120>

Marza, Suci Eryzka, 'Regulasi Diri Remaja Penghafal Al-Qur'an Di Pondok Pesantren Al-Qur'an Jami'atul Qurro' Sumatera Selatan', Intelektualita, $6.1 \quad$ (2017), 145 <https://doi.org/10.19109/intelektualita.v6i1.1306>

Mashud, Imam, 'Meningkatkan Kemampuan Dalam Setoran Hafalan Al-Qur'an Melalui Metode Talaqqi Pada Siswa Kelas Vib Sekolah Dasar Islam Yakmi Tahun 2018', NATURALISTIC: Jurnal Kajian Penelitian Pendidikan Dan Pembelajaran, 3.2 (2019), $347-58$ 
<https://doi.org/10.35568/naturalistic.v3i2.397>

Mufidah, Luk-Luk Nur, 'Memahami Gaya Belajar Untuk Meningkatkan Potensi Anak', Martabat: Jurnal Perempuan Dan Anak, 2017

<https://doi.org/10.21274/martabat.2017.1.2.245-260>

Muhammad Iqbal Ansari, 'Pelaksanaan Karantina Tahfidzh AlQur'an 30 Hari Untuk Siswa Sekolah Dasar Dan Madrasah Ibtidaiyah Di Banjarmasin', Jurnal Madrasah Ibtidaiyah, 2.2 (2017), 1-18

Pamungkas Stiyamulyani, Pamungkas Stiyamulyani, and Sri Jumini Sri Jumini, 'Pengaruh Menghafal Al-Qur'an Terhadap Highorder Thingking Skils (Hots) Ditinjau Dari Motivasi Berprestasi Mahasiswa', SPEKTRA: Jurnal Kajian Pendidikan Sains, $\quad 4.1 \quad$ (2018),

<https://doi.org/10.32699/spektra.v4i1.43>

Prayoga, Ari, Rizqia Salma Noorfaizah, Yaya Suryana, and Mohammad Sulhan, 'Manajemen Pembelajaran Tahfidzul Quran Berbasis Metode Yaddain Di Mi Plus Darul Hufadz Sumedang', Nidhomul Haq : Jurnal Manajemen Pendidikan Islam, 4.2 (2019), $140-56$

<https://doi.org/10.31538/ndh.v4i2.326>

Qur, Dimensi-dimensi Psikologis Tahfidz Al-, Abdul Rohman, Madrasah Ibtidaiyyah, Quran Kudus, and Central Java, 'Jurnal Intelegensia - Vol. 04 No. 2 Juli-Desember 2016 | 78', 04.2 (2016), 78-112

Rijal Mustaqim, Moh, and Hanifah Nurhaedha, 'Management of Halaqah Tahfidz Al-Qur'an in Darut Taqwa Ponorogo Islamic Boarding School', Jumal Tarbiyatuna, 11.2 (2020), 12842

$<$ http://journal.ummgl.ac.id/index.php/tarbiyatuna/article/ view/3040>

Rohmad, Rohmad, and Muslimin Muslimin, 'Tahfidz Al-Quran Dengan Metode Bil-Qolam Di Madrasah Tsanawiyah (Islamic Boarding School) Al- Azhary Ajibarang Banyumas', MAGHZA: Jurnal Ilmu Al-Qur'an Dan Tafsir, 2.2 (2017), 9199 <https://doi.org/10.24090/maghza.v2i2.1572> 
Mochammad Ashabul Yamin, Anita Puji Astutik

Syahid, Akhmad, 'Tren Program Tahfidz Al-Qur'an Sebagai Metode Pendidikan Anak', Elementary: Jurnal Ilmiah Pendidikan Dasar, $\quad 5.1 \quad$ (2019), $\quad 87$ <https://doi.org/10.32332/elementary.v5i1.1389>

Tarbiyah, Fakultas, D A N Keguruan, Universitas Islam Negeri Ar-raniry, and Darussalam Banda Aceh, 'Pengelolaan Program Tahfidz Dalam Pembentukan', 2018, 32-44

Yayasan, D I, Karantina Tahfid, Z H Qur, and A N Nasional, 'Metode Pembelajaran Tahfid Zul Qur'an Di Yayasan Karantina Tahfid Zh Qur'an Nasional (Yktn) Salatiga Tahun 2019 Skripsi', 2019 